\title{
Pengaruh Metode Bermain Terhadap Kemampuan Passing
}

\author{
Akrimul Insanul Kamil ${ }^{1}$, Damrah², Pudia M Indika ${ }^{3}$ \\ ${ }^{123}$ Fakultas Ilmu Keolahragaan, Universitas Negeri Padang, Indonesia.
}

E-mail: akrimulkamil@yahoo.com ${ }^{1}, \underline{\text { damrah@fik.unp.ac.id }}{ }^{2}$, pudia_dr@fik.unp.ac.id ${ }^{3}$

\begin{abstract}
Abstrak
Masalah dalam penelitian ini adalah rendahnya kemampuan Passingpemain SSB Bina Remaja Lumindai Kota Sawahlunto. Tujuan penelitian ini untuk membuktikan pengaruh metode bermain terhadap peningkatan kemampuan passing pemain SSB Bina Remaja Lumindai Kota Sawahlunto.

Penelitian ini bersifat eksperimen semu yaitu memberikan perlakuan terhadap pemain SSB Bina Remaja Lumindai Kota Sawahlunto.Penelitian ini dilakukan dari bulan Mei sampai bulan Juli tahun 2018 di lapangan sepakbola SSB Bina Remaja Lumindai Kota Sawahlunto. Populasi dalam penelitian ini adalah Seluruh anggotanya terdiri dari kelompok pemula sampai kelompok senior terdiri atas 40 orang. Teknik pengambilan sampel adalah purposive sampling, sampel yaitu sebanyak 20 orang. Data dianalisis dengan menggunakan teknik inferensial dengan formula uji ' $t$ ' sampel terikat.

Hasil yang diperoleh dalam penelitian adalah sebagai berikut : didapat hasil dari pengujian tersebut dengan skor $t_{\text {hit }} 11,95$ untuk tab pada taraf signifikan $\alpha=0,05$ yaitu 1,729 , karena $t_{\text {hit }}>t_{\text {tab }}$ atau $11,95>1,729$ maka terdapat pengaruh yang berarti metode bermain terhadap peningkatan kemampuan passingpemain SSB Bina Remaja Lumindai Kota Sawahlunto.
\end{abstract}

Kata Kunci: Metode Bermain, Kemampuan Passing

\begin{abstract}
The problem in this study is the low ability of the SSB Bina Remaja ScanOSS Teenager Passing ability in Sawahlunto City. The purpose of this study was to prove the effect of playing methods on increasing the passing ability of SSB Bina Remaja Lumindai City players in Sawahlunto City.

This research is a quasi-experimental research which is to give treatment to the SSB B Lumina Youth Students in Sawahlunto City. This research was conducted from May to July 2018 at the SSB Bina Remaja Lumindai Sawahlunto soccer field. The population in this study were all members of the group consisting of beginners to senior groups consisting of 40 people. The sampling technique was purposive sampling, a sample of 20 people. Data were analyzed using inferential techniques with the formula t'bound sample test formula.

The results obtained in the study are as follows: the results of these tests with a thit score of 11.95 for ttab at a significant level $\alpha=0.05$ is 1.729 , because $t$ hithit $>$ ttab or $11.95>1.729$ there is a significant influence playing method to improve the passing ability of the SSB Bina Remaja Lumindai City of Sawahlunto.
\end{abstract}


Sport Science: Jurnal Sain Olahraga dan Pendidikan Jasmani ISSN 114-562X (Cetak), ISSN XXXX-XXXX(Online)

http://sportscience.ppj.unp.ac.id/index.php/jss/index

Keywords: Playing Method, Passing Ability

\section{PENDAHULUAN}

Dalam usaha untuk mengembangkan prestasi pada cabang olahraga sepakbola, maka banyak di dirikan klub sekolah sepakbola usia dini di Sawahlunto, seperti : SSB Bina Remaja Lumindai, SSB Talawi Putra, SSB PSKS, SSB Garuda Santur, SSB Tanah Lapang, SSB Talago Gunung dan SSB FORMAS Muaro Kalaban. SSB Bina Remaja Lumindai merupakan salah satu SSB yang aktif di kota Sawahlunto. SSB Bina Remaja Lumindai ini didirikan pada tahun 2010, SSB didirikan karena banyaknya potensi bermain sepakbola pada anak-anak usia dini di Lumindai.

Di SSB Bina Remaja Lumindai Kota Sawahlunto kegiatan olahraga sepakbola telah berjalan sesuai dengan program latihan yang telah dibuat oleh pelatih serta Pembina kegiatan SSB, akan tetapi peningkatan permainan belum banyak dirasakan, hal ini terlihat pada waktu SSB Bina Remaja Lumindai bertanding di setiap even-even pertandingan. Berdasarkan wawancara penulis dengan pelatih SSB Bina Remaja Lumindai di lapangan, prestasi atlet sepakbola SSB Bina Remaja Lumindai tidak terlalu baik dan cenderung menurun. Hal ini tergambar dari sekian banyak pertandingan antar SSB yang pernah mereka ikuti, pencapaian terbaik mereka hanyalah menjadi semifinalis pada tahun 2015, sedangkan sisanya mereka sering kandas di fase grup dan fase perempat final( 8 besar). Salah satu penyebab kekalahan yang sering mereka alami dalam melaksanakan pertandingan adalah seringnya pemain melakukan kesalahan dalam passing.

Dari pengamatan yang penulis lakukan pada beberapa pertandingan uji coba dan kompetisi yang mereka ikuti, ternyata masalah dalam melakukan passing memang terlihat, mereka sering salah atau tidak tepat sasaran dalam melakukan passing sehingga tim tidak bermain bagus dan sering mengalami kekalahan. Kesalahan dalam melakukan passing ini sering terlihat, pemain sering tidak tepat sasaran pada saat passing yang mengakibatkan bola dapat direbut oleh tim lawan. Menurut penulis, masalah tersebut menunjukkan bahwa lemahnya kemampuan passing pemain SSB Bina Remaja Lumindai.

Dalam usaha meningkatkan kemampuan passing di SSB Bina Remaja Kota Sawahlunto, telah diberikan latihan passing terhadap pemain, akan tetapi hasil yang akan diharapkan belum juga didapatkan. Lambannya peningkatan tersebut diantaranya disebabkan karena belum tersedianya bentuk latihan yang tepat dalam meningkatkan kemampuan passing pemain SSB Bina Remaja Lumindai Kota Sawahlunto. Dalam hal ini penulis mencoba memilih dan memfokuskan pada metode bermain yang penulis anggap sesuai dan diharapkan dapat meningkatkan kemampuan passing khususnya untuk atlet SSB Bina Remaja Lumindai.

Karena menurut penulis dengan metode bermainpara pemain dapat lebih aktif dan lebih banyak mengekspresikan gerakan individu. Hal ini yang membuat pemain lebih senang dan tidak merasa jenuh saat latihan karena hakekatnya bermain adalah kegiatan yang menyenangkan, terkhusus bagi anak-anak sekolah sepak bola.Dalam pelaksanaan latihan metode bermain ini, pemain dapat mempelajari sekaligus teknik yang terdapat didalamnya sebagai suatu unit yang utuh.Pada keterampilan bermain sepakbola yang menggunakan metode bermain, pemain dituntut untuk memecahkan masalah secara individu, seperti mengkoordinasikan semua satuan-satuan gerakan atau fase-fase yang ada.

Memperkenalkan keterampilan pada pemain merupakan suatu upaya untuk memotivasi keterampilan pemain dalam berlatih. Oleh sebab itu penulis berharap dengan metode bermain ini pemain SSB Bina Remaja Lumindai Kota Sawahlunto dapat meningkatkan kemampuan passing tiaptiap pemainnya. Untuk memperoleh passing yang baik dipengaruhi oleh beberapa faktor seperti posisi badan pada saat menendang dan menahan bola, perkenaan kaki dengan bola, dan pandangan pada saat 
menendang bola. Selain itu faktor lain yang mempengaruhi passing seperti faktor internal dan faktor eksternal.

Faktor internal adalah potensi bawaan yang ada dalam diri atlet itu sendiri seperti: bakat secara umum (teknik dan taktik), aspek psikologis (mental bertanding, mental latihan, keseriusan dalam berlatih disiplin dan lain sebagainya), aspek fisiologis (kesehatan, status gizi, serabut otot dan lain sebagainya), kognitif termasuk intelegensi atlet umpanya kemampuan menyerap informasi dan mampu mengaplikasikannya. Sedangkan faktor eksternal yaitu faktor yang berada diluar diri atlet seperti: pelatih beserta programnya, faktor lingkungan, faktor cuaca, faktor lapangan, faktor sarana prasarana dan faktor lainnya. Jadi jelas bahwa komponen ini sangat diperlukan sekali dalam melakukan passing supaya lebih maksimal.

Metode bermain merupakan cara berlatih teknik yang dilakukan dalam bentuk permainan, menurut Koger (2007: 14). "Metode bermain adalah metode yang mengajarkan suatu keterampilan psikomotorik dengan cara peragaan teknik kemudian mempraktikkannya dalam proses permainan". Dimana pengajaran latihan gerakan suatu keterampilan dipelajari mulai dari awal gerakan dimana adanya proses bermain. Bentuk-bentuk latihan teknik passing dalam format small game, dan bermain sebagai berikut:

\section{a. Passing kejar-kejaran}

Keterangan : ukuran lapangan $7 \times 7 \mathrm{~m}$, pemain 4 vs 2, peraturannya empat orang yang menguasai bola hanya memainkan bola dengan dua sentuhan, dua orang lainnya bertugas mengejar bola, jika salah satu dari dua orang yang mengejar bola tersebut mendapatkan bola, maka dia berganti posisi dengan pemain yang kehilangan bola. (Scheunemann (2012: 92).

\section{b. Possesion game}

Keterangannya : ukuran lapangan $25 \times 20 \mathrm{~m}$, pemain dibagi menjadi dua kelompok. 1) memainkan possesion game bebas sentuhan, selanjutnya turunkan jumlah sentuhan ke dua lalu satu sentuhan.2) sebagai variasi hanya diperbolehkan pemain menggunakan kaki kiri atau kaki kanan. 3) hukum pemain bagi umpannya yang melambung. 4) Sebagai variasi tambahkan seorang pemain bebas.(Scheunemann (2012: 182).

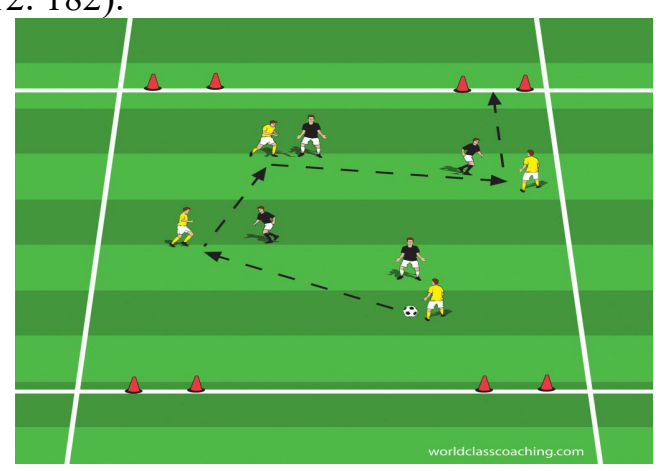

\section{Gambar 1. Pelaksanaan Teknik Passing Secara Bermain \\ Sumber : www.worldclasscoaching.com}

\section{c. Possesion game dengan tiga zona area}

Keterangan : 1) lapangan dibagi menjadi 3 bagian (I, II, III). 2) lakukan possesion game seluruh lapangan, kemudian instruksikan kepada pemain untuk hanya bermain dizona tertentu. Sebagai contoh tiup pluit 3 kali sebagai isyarat permainan hanya dilakukan di dalam zona III. Tiup pluit satu disusul dengan tiup pluit ketiga kali sebagai isyarat permainan hanya dibolehkan dizona I dan II. Fungsi latihan ini untuk membiasakan pemain melakukan passing pendek dan panjang secara bergantian.( Scheunemann (2012: 183).

Dari uraian diatas dapat disimpulkan bahwa pembelajaran dengan pendekatan metode permainan adalah merupakan suatu cara atau pendekatan dalam memberikan materi latihan yang 
dilaksanakan dalam situasi bermain yang diurutkan dari bentuk permainan yang sederhana ke urutan yang lebih sulit menuju permainan yang sebenarnya sehingga anak dalam berlatih kemampuan dasar bermain sepakbola tidak merasa bosan. Dengan kata lain anak termotivasi dalam berlatih untuk meraih prestasi.

Dalam proses latihan gerakkan dalam olahraga sepakbola terutama kemampuan passing yang menjadi pokok permasalahannya adalah bagaimana materi atau bahan latihan tersebut disajikan kepada atlet dengan sedemikian rupa. Sehingga pada akhirnya tujuan yang ditetapkan sebelumnya tercapai secara efektif dan efisien. Sehubungan dengan hal tersebut, maka yang menjadi permasalahan adalah apakah metode bermain mampu meningkatkan kemampuan passingdengan diberikan secara bentuk latihan sehingga tercapainya hasil latihan yang optimal berdasarkan pada tujuan yang ditetapkan.

Untuk melatih gerakkan pada kemampuan passing dengan menggunakan metode bermain dapat dilakukan dengan cara melatih teknik -teknik dalam bentuk permainan dari keseluruhan teknikteknik secara akurat yang terdapat pada sepakbola untuk mendapatkan kemampuan passing dan setelah materi disajikan. Dalam proses latihan atau belajar yang menggunakan metode bermain, anak dituntut untuk memecahkan masalah secara sendiri, seperti aktif dan mampu untuk melakukan gerakan-gerakan teknik yang diajarkan. Disamping itu penerapan dalam metode ini dapat meningkatkan kemampuan daya tangkap pemain, karena gerakan yang ditampilkan secara berulangulang. Dengan menerapkan kemampuan passing secara bermain diharapkan dapat meningkatkan hasil latihan.

\section{METODE}

Jenis penelitian yang dilaksanakan ini adalah eksperimental semu. Menurut Nazir (2003:27)"penelitian eksperimen semu adalah penelitian mendekati percobaan sesungguhnya dimana tidak akan mengadakan kontrol, manipulasi semua variabel yang relevan". Penelitian ini akan dilakukan dua tes, yaitu tes awal sebelum diberikan perlakuan dan tes akhir setelah diberikan perlakuan. Dengan demikian penelitian ini akan melihat seberapa besar pengaruh metode bermain terhadap kemampuan passing pemain SSB Bina Remaja Lumindai Kota Sawahlunto setelah diberikan program latihan selama 16 kali pertemuan.

Penelitian ini dilaksanakan di lapangan sepakbola SSB Bina Remaja Lumindai Kota Sawahlunto. Penelitian ini dilakukan pada bulan September - Desember 2018. Populasi merupakan sekumpulan obyek yang diteliti yang memiliki minimal satu karakteristik yang sama dari seluruh anggotanya (Suwirman, 2015:50). Populasi dalam penelitian ini adalah anggota SSB Bina Remaja Lumindai Kota Sawahlunto. Seluruh anggotanya terdiri dari kelompok pemula sampai kelompok senior terdiri atas 40 orang.

Tabel 1. Jumlah Pemain SSB Bina Remaja Lumindai Kota Sawahlunto

\begin{tabular}{ccc}
\hline NO & KELOMPOK UMUR & JUMLAH \\
\hline 1. & U-14 tahun & 20 orang \\
2. & U-16 tahun & 20 orang \\
& JUMLAH & $\mathbf{4 0}$ orang \\
\hline
\end{tabular}

\section{Sumber : Sekolah Sepakbola Bina Remaja Lumindai Kota Sawahlunto}

Sampel adalah sebagian atau wakil populasi yang diteliti (Arikunto, 2010:174). Berdasarkan populasi diatas, yang dijadikan sampel dalam penelitian ini adalah anggota pemain SSB Bina Remaja Lumindai Kota Sawahlunto U-16 yaitu sebanyak 20 orang yang dimana penarikan sampel dilakukan dengan teknik purposive sampling. Purposive Sampling adalah teknik pengambilan sampel sumber data dengan pertimbangan tertentu. Kelompok U-16 adalah tim yang masih aktif di SSB Bina Remaja Lumindai Kota Sawahlunto, oleh sebab itu peneliti mengambil sampelU-16 .

\section{Prosedur Penelitian}

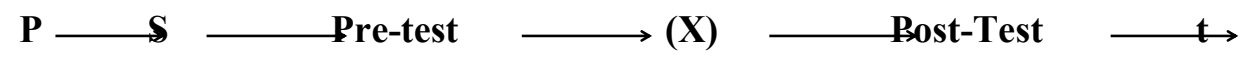




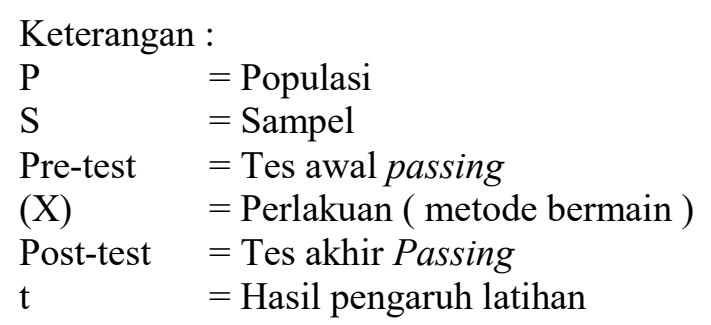

Data yang diperlukan dalam penelitian ini adalah hasil passing yang dilakukan atlet. Untuk mendapatkan data dalam penelitian ini, terlebih dahulu dibuat langkah-langkah sebagai berikut :

1. Langkah Persiapan.

Pada langkah persiapan ini harus mempersiapkan segala sesuatu yang dibutuhkan dalam pelaksanaan tes antara lain mendapatkan surat izin dari Dekan Fakultas Ilmu Keolahragaan Universitas Negeri Padang.

2. Izin dari SSB Bina Remaja.

3. Menetapkan Peralatan yang dibutuhkan dalam penelitian.

Sebelum dilakukan tes dalam, terlebih dahulu di persiapkan alat-alat pengupul data, adapun alat-alat yang dibutuhkan antara lain : (a) Meteran, (b) Stopwatch, (c) Cone/patok, (d) Peluit, (e) Bola, (f) Format isian, (g) Alat-alat tulis.

4. Menyiapkan tenaga pembantu dan pengawas.

Berikut daftar pengawas dan pembantu dalam penelitian ini :

Tabel 2. Pengawas dan Tenaga Pembantu Tes

\begin{tabular}{cccc}
\hline No & Nama & Jabatan & Tugas \\
\hline 1 & Angga Nasrul & Pelatih & Pengawas Tes \\
2 & Dedi Hulung & Asisten Pelatih & Pembaca Skor \\
3 & Beny Yusra & Pelatih Kiper & Pencatat Skor \\
4 & Vikry & Perlengkapan & Pencatat Skor \\
\hline
\end{tabular}

5. Pelaksanaan Tes Awal (Pre Test).

Pelaksanaan tes terdiri dari tes awal (Pre test) dan tes akhir (Post test). Pre test yaitu test yang dilakukan sebelum diberikan perlakuan. Sebelum dilakukan Pre test peneliti harus memeriksa kesehatan, kelainan anatomi, maupun cedera yang pernah dialami atau sedang dialami peserta test.

6. Memberikan Latihan (perlakuan).

Latihan ini dilaksanakan selama 16 kali selama 6 minggu dengan jadwal latihan 3 kali seminggu yaitu hari Selasa, Kamis dan Sabtu.

7. Melaksanakan Tes Akhir (Post Test).

Post test yaitu test yang dilakukan setelah diberikan perlakuan Setelah pemberian latihan passing dalam bermain dan latihan passing dalam bentuk latihan dengan variasi selama 16 kali pertemuan. Kemudian dilakukan tes kemampuan passing.

Agar proses latihan dapat berjalan dengan baik, lancar dan tujuan latihan/penelitian yang diharapkan tercapai yaitu menigkatkan kemampuan dasar bermain sepakbola SSB Bina Remaja Lumindai Kota Sawahlunto U-16.

\section{Instrument Penelitian}

Untuk mengkaji lebih lanjut mengenai akurasi passing test yang dilakukan adalah testshort pass (Arsil (2015:141). Test keterampilan ini memiliki validitas tes adalah 0,66 dan reliabelitas tes 0,69 . 
1. Test ini yang bertujuan untuk mengetahui kemampuan dan keterampilan dalam melakukan passing secara tepat dan cepat.

2. Alat yang dibutuhkan adalah:
a. Meteran
b. Cons/ Patok
c. Bola
d. Sebuah lapangan sepakbola
e. Stopwatch
f. Peluit
g. Alat tulis menulis
h. Blangko penelitian

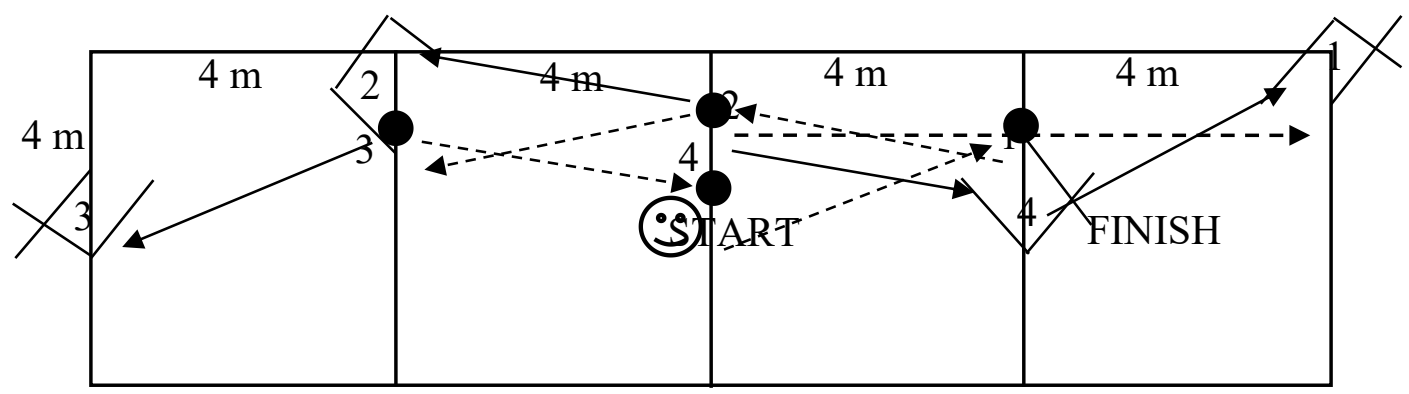

Gambar 2. Denah Dan Ukuran Lapangan Saat Test

Sumber: Arsil (2015: 141)

Keterangan :

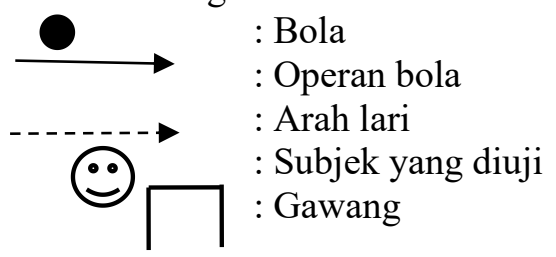

3. Prosedur pelaksanaan :

a. Peserta tes berada dibelakang garis start, Pada aba-aba "ya" peserta tes lari kearah bola 1 dan menendang ke sasaran 1.

b. Selanjutnya lari menuju bola 2 dan menendang ke sasaran 2 .

c. Selanjutnya lari menuju bola 3 dan menendang ke sasaran 3

d. Selanjutnya lari menuju bola 4 dan menendang ke sasaran 4 dan akhirnya lari menuju garis finis

4. Penilaian bagaimana tes dilakukan

Penilaian dihitung setelah semua bola ditendang ke sasaran dengan waktu maksimal.

5. Norma.

Tabel 3.Transformasi skor Test Short Pass (Waktu)ke dalam T-Score

\begin{tabular}{cccc}
\hline T-SCORE & Short Pass Test (/10 detik) & T-SCORE & Short Pass Test (/10 detik) \\
\hline 90 & $-<3.00$ & 46 & $11.14-11.30$ \\
84 & $3.01-4.00$ & 45 & $11.31-11.50$ \\
68 & $4.01-7.09$ & 44 & $11.51-11.70$ \\
67 & $7.10-7.32$ & 43 & $11.71-11.81$ \\
65 & $7.33-7.69$ & 42 & $11.82-12.00$ \\
64 & $7.70-7.89$ & 41 & $12.01-12.20$
\end{tabular}




\begin{tabular}{llll}
63 & $7.90-8.11$ & 40 & $12.21-12.42$ \\
62 & $8.12-8.30$ & 39 & $12.43-12.47$ \\
61 & $8.31-8.46$ & 38 & $12.48-12.70$ \\
60 & $8.47-8.68$ & 37 & $12.71-13.03$ \\
59 & $8.69-8.81$ & 36 & $13.04-13.20$ \\
58 & $8.82-9.06$ & 35 & $13.21-13.40$ \\
57 & $9.07-9.21$ & 34 & $13.41-13.59$ \\
56 & $9.22-9.44$ & 33 & 13.60 \\
55 & $9.45-9.62$ & 32 & $13.61-13.80$ \\
54 & $9.63-9.80$ & 31 & $13.81-14.09$ \\
53 & $9.81-10.00$ & 30 & $14.10-14.20$ \\
52 & $10.01-10.15$ & 29 & $14.21-14.40$ \\
51 & $10.16-10.38$ & 28 & $14.41-14.60$ \\
50 & $10.39-10.57$ & 25 & $14.61-15.20$ \\
49 & $10.58-10.74$ & 22 & $15.21-15.70$ \\
48 & $10.75-10.92$ & 20 & $15.71-16.10$ \\
47 & $10.93-11.13$ & 19 & $16.11-19.78$ \\
\hline
\end{tabular}

Sumber : Arsil (2015:142-143)

Tabel 4. Transformasi skor Test Short Pass (Bola Masuk)ke dalam T-Score

\begin{tabular}{cc} 
T-SCORE & SHORT PAST (10/detik) \\
\hline 66 & 4 \\
55 & 3 \\
45 & 2 \\
34 & 1 \\
\hline Sumber : Arsil (2015:142-143)
\end{tabular}

Tabel 5. Norma penilaian Test Short Pass(T-Score Waktu + Bola masuk)

\begin{tabular}{cll}
\hline NO & Klasifikasi T-Score & T-Score \\
\hline 1 & Baik Sekali & $>124$ \\
2 & Baik & $104-123$ \\
3 & Sedang & $85-103$ \\
4 & Kurang & $65-84$ \\
5 & Kurang Sekali & $<64$ \\
\hline
\end{tabular}

\section{A. Teknik Analisis Data}

\section{Sumber : Arsil (2015:142-143)}

Teknik analisis data yang digunakan dengan memakai uji $\mathrm{t}$ (dependent sampel). Menurut Tim Mata Kuliah Statistik (2017:42) "Sampel dikatakan berhubungan/tidak bebas apabila keberadaan satu sampel pada satu kelompok ada kaitannya dengan keberadaan sampel lainnya pada kelompok lain. Sampel yang berhubungan ini, mungkin hanya satu sampel tetapi dikenakan perlakuan dua kali, atau dua sampel yang disamakan atas dasar variabel tertentu (variabel terikat), tetapi kedua sampel tersebut mendapatkan perlakuan yang berbeda.

\section{HASIL DAN PEMBAHASAN \\ Hasil Penelitian}

Pada hasil pengukuran dan analisis data dari hasil tes awal kemampuan passing pemain SSB Bina Remaja Lumindai Kota Sawahlunto sebelum pemberian program latihan metode bermain dan hasil tes akhir kemampuan passing pemain SSB Bina Remaja Lumindai Kota Sawahlunto setelah pemberian program metode bermain.

\section{Tes Awal Kemampuan Passing}


Sport Science: Jurnal Sain Olahraga dan Pendidikan Jasmani ISSN 114-562X (Cetak), ISSN XXXX-XXXX(Online)

http://sportscience.ppj.unp.ac.id/index.php/jss/index

Berdasarkan hasil tes awal kemampuan Passing yang dilakukan, diperoleh skor maksimum $=103$, skor minimum $=65$ simpangan baku $(\mathrm{SD})=11,76$ dan diperoleh nilai mean (rata-rata) kemampuan Passing $=83,85$. Agar lebih jelasnya data tes awal kemampuan Passing dapat dilihat pada table 6 di bawah ini :

Tabel 6. Distribusi Frekuensi Tes Awal Kemampuan Passing

\begin{tabular}{lccc}
\hline Kelas Interval & fa & Fr & Klasifikasi \\
\hline$>124$ & 0 & 0 & BaikSekali \\
$104-123$ & 0 & 0 & Baik \\
$85-103$ & 9 & $45 \%$ & Sedang \\
$65-84$ & 11 & $55 \%$ & Kurang \\
$<64$ & 0 & 0 & KurangSekali \\
JUMLAH & 20 & & $100 \%$ \\
\hline
\end{tabular}

Berdasarkan tabel distribusi frekuensi tes awal kemampuan Passing dari 20 orang sampel, 9 orang (45\%) yang memperoleh kemampuan Passing dengan klasifikasi sedang, 11 orang (55\%) yang memperoleh kemampuan Passing dengan klasifikasi kurang dan tidak ada yang memperoleh kemampuan Passing dengan klasifikasi baik sekali, klasifikasi baikdanklasifikasi kurangsekali.Untuk lebih jelasnya, distribusi frekuensi tes awal kemampuan Passing diatas juga dapat dilihat pada histogram dibawah ini:

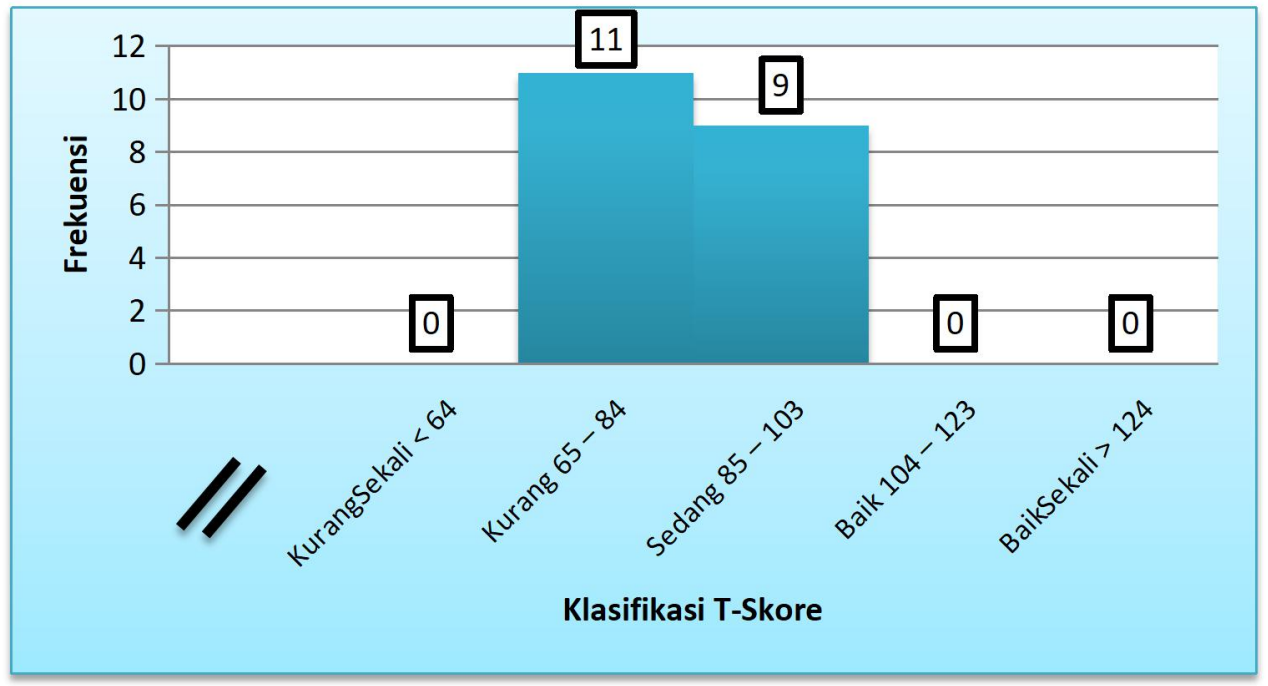

Gambar 8 : Histogram Tes Awal Kemampuan Passing

Berdasarkan histogram di atas kemampuan Passing yang berada pada rata-rata sebanyak 9 orang (45\%), sisanya berada di bawah rata- rata sebanyak 11 orang (55\%).

2. Tes Akhir Kemampuan Passing

Berdasarkan hasil tes akhir kemampuan Passing yang dilakukan, diperoleh skor maksimum $=134$, skor minimum $=97$ simpangan baku $(S D)=10,82$ dan diperoleh nilai mean (rata-rata) kemampuan Passing $=117,65$. Agar lebih jelasnya data tes akhir kemampuan Passing dapat dilihat pada tabel 7 di bawah ini :

Tabel 7. Distribusi Frekuensi Tes Akhir Kemampuan Passing

$\begin{array}{lccc}\text { Kelas Interval } & \mathbf{F a} & \mathbf{F r} & \text { Klasifikasi } \\ >124 & 6 & 30 \% & \text { BaikSekali }\end{array}$




$$
\begin{gathered}
104-123 \\
85-103 \\
65-84 \\
<64-0 \\
\text { JUMLAH }
\end{gathered}
$$

$\begin{array}{cc}12 & 60 \% \\ 2 & 10 \% \\ 0 & 0 \\ 0 & 0 \\ 20 & \end{array}$

Baik

Berdasarkan tabel distribusi frekuensi tes akhir kemampuan Passingdari 20 orang sampel, 6 orang (30\%) memperoleh kemampuan Passing dengan klasifikasi BaikSekali, 12 orang (60\%) memperoleh kemampuan Passing dengan klasifikasi baik, 2 orang (10\%) memperoleh kemampuan Passing dengan klasifikasi Sedang.Secara lebih jelas kemampuan passing pemain SSB Bina Remaja Lumindai Kota Sawahlunto pada akhir perlakuan dapat dilihat pada grafik histogram dibawah ini:

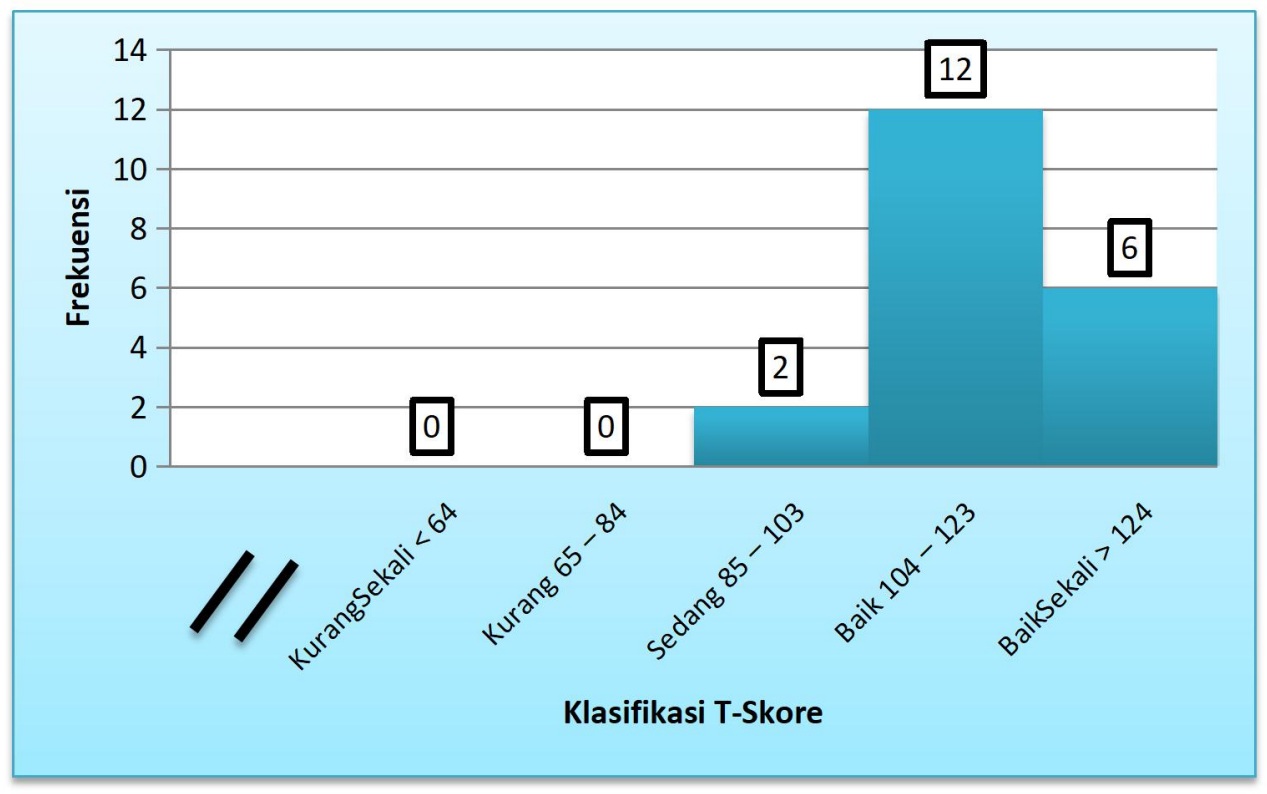

Gambar 9 : Histogram Tes Akhir Kemampuan Passing

Berdasarkan histogram di atas kemampuan Passing yang berada di atas rata-rata sebanyak 12 orang $(60 \%)$, berada di bawah rata- rata sebanyak 2 orang $(10 \%)$ dan yang berada di dalam kelompok rata-rata sebanyak 6 orang (30\%). Dapat disimpulkan tes akhir kemampuan Passing yang berada di dalam kelompok diatas rata-rata lebih banyak dari yang berada di kelompok rata-rata maupun di bawah kelompok rata-rata.

Pengujian normalitas masing-masing distribusi frekuensi dilakukan dengan uji liliefors. Hasil pengujian normalitas tes awal kemampuan Passing dan tes akhir kemampuan Passingdapat dilihat pada tabel 8 berikut ini.

Tabel 8. Rangkuman uji normalitas sebaran data dengan uji lilliefors

\begin{tabular}{cccccc}
\hline No & Variabel & N & $\mathbf{L}_{\mathbf{o}}$ & $\mathbf{L}_{\text {tab }}$ & Distribusi \\
\hline 1 & Tes Awal Kemampuan Passing & 20 & 0,094 & 0.190 & Normal \\
2 & Tes Akhir Kemampuan Passing & 20 & 0.138 & 0.190 & Normal \\
\hline
\end{tabular}

Tabel di atas menunjukkan bahwa hasil pengujian untuk tes awal kemampuan Passing, skor $\mathrm{L}_{\mathrm{o}}=0,094$ dengan $\mathrm{n}=20$, sedangkan $\mathrm{L}_{\text {tab }}$ pada taraf pengujian signifikan $\alpha=0,05$ diperoleh 0,190 yang lebih besar dari $\mathrm{L}_{0}$ sehingga dapat disimpulkan bahwa skor yang diperoleh dari tes awal kemampuan Passing berdistribusi normal. Tabel di atas menunjukkan bahwa hasil pengujian untuk tes 
akhir kemampuan Passing, skor $\mathrm{L}_{\mathrm{o}}=0,138$ dengan $\mathrm{n}=20$, sedangkan $\mathrm{L}_{\text {tab }}$ pada taraf pengujian signifikan $\alpha=0,05$ diperoleh 0,190 yang lebih besar dari $\mathrm{L}_{\mathrm{o}}$ sehingga dapat disimpulkan bahwa skor yang diperoleh dari tes akhir kemampuan Passing berdistribusi normal. Berdasarkan uraian di atas ternyata semua variabel tersebar secara normal, karena masing-masing variabel skor $\mathrm{L}_{\mathrm{o}}$ nya lebih kecil dari pada $\mathrm{L}_{\text {tab }}$ pada taraf pengujian signifikan $\alpha=0,05$.

\section{T-Test Dua Sampel Berpasangan}

Uji ini bertujuan melihat, apakah dua sampel berpasangan mempunyai rata-rata berbeda atau tidak. Uji ini dilakukan dua sisi (2-tailed) karena akan diketahui rerata kesamaan satu dengan kesamaan dua, sama atau tidak (besar atau lebih kecil). Sampel berpasangan (pairedsampel) merupakan sebuah sampel dengan subjek yang sama, namun mengalami dua pengukuran yang berbeda. Dalam hal ini hasil analisis menampilkan apakah metode bermain berpengaruh terhadap kemampuan passingpemain SSB Bina Remaja Lumindai Kota Sawahlunto.

Berdasarkan perhitungan yang telah dilakukan dengan menggunakan uji-t maka didapat $t_{\text {hitung }}$ sebesar 11,95, sedangkan $t_{\text {tabel }}$ pada $\alpha .005$ dan derajat kebebasan (dk) n-1 adalah sebesar 1,729, maka $t_{\text {hitung }}>t_{\text {tabel }}(11,95>1,729)$ (Ha diterima dan $\mathrm{H0}$ ditolak) jadi dapat disimpulkan bahwa hipotesis yang menyatakan terdapat pengaruh metode bermain terhadap peningkatan kemampuan passing pemain SSB Bina Remaja Lumindai Kota Sawahlunto dapat diterima kebenarannya secara empiris. Berikut tabel perbandingan antar $t_{\text {hitung }}$ dengan $t_{\text {tabel }}$ :

Tabel 9. Hasil Uji t Tes Awal Dan Akhir Kemampuan Passing

\begin{tabular}{cccccc}
\hline Metode Bermain & Mean & $\mathbf{t}_{\text {hitung }}$ & $\mathbf{A}$ & $\mathbf{t}_{\text {tabel }}$ & Kesimpulan \\
\hline tes awal & 83,85 & \multirow{2}{*}{11,95} & 0.05 & \multirow{2}{*}{1,729} & Signifikan \\
tes akhir & 117,65 & & & \\
\hline
\end{tabular}

Dari pengolahan data yang telah dilakukan dengan menggunakan uji t, didapat hasil dari pengujian tersebut dengan skor $t_{\text {hit }} 11,95$, sedangkan $t_{\text {tab }}$ yang dilihat pada daftar uji t pada taraf 0,05 dengan derajat kebebasan $(\mathrm{dk})=\mathrm{n}-1=20-1=19$ adalah 1,729. karena $\mathrm{t}_{\mathrm{hit}}>\mathrm{t}_{\mathrm{tab}}$ atau 11,95 $>1,729$ maka terdapat pengaruh yang berarti metode bermain terhadap kemampuan passingpemain SSB Bina Remaja Lumindai Kota Sawahlunto.

\section{B. Pembahasan}

Dari perhitungan uji $\mathrm{t}$ antara pengaruh metode bermain terhadap kemampuan Passing diperoleh $t_{\text {hit }} 11,95$ untuk $t_{\text {tab }}$ pada taraf signifikan $\alpha=0,05$ yaitu 1,729 . Berarti dalam hal ini terdapat pengaruh yang berarti metode bermain terhadap peningkatan kemampuan passingpemain SSB Bina Remaja Lumindai Kota Sawahlunto. Dari hasil analisis diatas dapat diambil kesimpulan bahwa Latihan metode bermain dapat membuat perubahan yang berarti untuk kemampuanPassing pemain sepak bola, apabila latihan metode bermain dilakukan dengan benar dan pemberian dosis latihan yang tepat akan memberi pengaruh kemampuan Passing atlet SSB Bina Remaja Lumindai Kota Sawahlunto.

Bermain tidak mempunyai batas usia karena setiap manusia dalam umur yang berbeda pasti menyukai kegiatan bermain. Menurut Tedjasaputra MS (2001: 2) bermain adalah hal berkaitan dengan kegiatan yang memberikan efek kepuasaan dalam prosesnya. Baik disadari maupun tidak aktivitas ini akan berjalan apabila dilakukan secara lepas tanpa beban. Hal ini dikarenakan kegiatan ini walaupun bersifat fisik tapi dampaknya sangat berpengaruh pada hal psikis. Psikis yang terpuaskan akan sejalan dengan harapan bahwa proses transformasi nilai berjalan sempurna.

Dimaksud dengan bermain adalah kegiatan yang sangat disenangi oleh anak. Sama halnya dengan karakteristik dari siswa SMA yang masih dominan kegiatannya adalah bersosialisasi dengan banyak teman. Secara psikologis beban mereka tidak menitikberatkan pada aspek hasil tapi masih dalam aspek proses. 
Metode bermain dapat para pemain lebih aktif dan lebih banyak mengekspresikan gerakan individu. Hal ini yang membuat pemain lebih senang dan tidak merasa jenuh saat latihan karena hakekatnya bermain adalah kegiatan yang menyenangkan, terkhusus bagi anak-anak sekolah sepak bola. Metode bermain akan lebih efektif dilakukan dalam meningkatkan kemampuan passing pemain sepakbola jika metode latihannya bervariasi. Dalam pelaksanaan latihan metode bermain ini, pemain dapat mempelajari sekaligus teknik yang terdapat didalamnya sebagai suatu unit yang utuh. Pada keterampilan bermain sepakbola yang menggunakan metode bermain, pemain dituntut untuk memecahkan masalah secara individu, seperti mengkoordinasikan semua satuan-satuan gerakan atau fase-fase yang ada.

Memperkenalkan keterampilan pada pemain merupakan suatu upaya untuk memotivasi keterampilan pemain dalam berlatih. Agar tujuan tersebut tercapai, upaya memperkenalkan keterampilan teknik dasar harus dikaitkan dengan makna dan manfaat bagi pemain yang bersangkutan. Makna dari kata bermain oleh masyarakat luas telah ditafsirkan bermacam-macam, dan kadangkadang makna tersebut berbeda-beda.

Metode bermain yang diaplikasikan dalam kegiatan latihan dapat meningkatkan kemampuan passing pemain terjadi karena kegiatan latihan tersebut menekankan pada aktifitas yang menyenangkan.Pada umumnya anak memiliki kecenderungan selalu aktif ingin bergerak sambil bersenang-senang untuk menyalurkan segala potensi tang ada pada dirinya.(Yudha. M Saputra, 2004) menjelaskan bermain sangat disukai.Dengan keaktifan tersebut maka isi latihan yang ingin disampaikan dapat teroptimalkan dengan baik. Pemain juga mampu menganalisis teknik passing dengan baik. Dalam melakukan latihan metode bermain untuk meningkatkan kemampuan passing dapat dilakukan dengan bentuk passing kejar-kejaran, possesion game dan possesion game dengan tiga zona area. Sehingga dalam melakukan latihan metode bermain terjadilah suatu peningkatan dalam kemampuan passingpemain SSB Bina Remaja Lumindai Kota Sawahlunto.

\section{KESIMPULAN}

Berdasarkan analisis data dan pembahasan, maka dapat dikemukakan kesimpulkan sebagai berikut : metode bermain memberi pengaruh yang berarti terhadap kemampuan passingpemain SSB Bina Remaja Lumindai Kota Sawahlunto, maka dapat dikemukakan bahwa pemain sepak bola untuk dapat meningkatkan kemampuan Passing yang dilakukan dengan melakukan latihan metode bermain secara berkelanjutan, para pelatih sepak bola dapat menerapkan program latihan dengan metode bermain dalam meningkatkan kemampuan Passing.

Para pembaca penelitian ini hanya terbatas pada 20 orang sampel, untuk itu perlu dilakukan penelitian pada jumlah sampel yang lebih banyak lagi. Kepada peneliti berikutnya diharapkan dapat menemukan program latihan lain yang bisa meningkatkan kemampuan Passing.

\section{DAFTAR RUJUKAN}

Arsil. (2015). Evaluasi Pendidikan Jasmani dan Olahraga. Malang : Wineka Media

Arikunto, Suharsimi. (1996). Prosedur Penelitian Suatu Pendekatan Praktek, Cetakan k-8. Yogyakarta: Rineka Cipta.

Eric, Batty. (1986). Latihan Sepak bola Metode Baru. Bandung: Pioneer Jaya.

Gifford, Clive. (2007). Keterampilan Sepak bola. Yogyakarta: PT Citra Aji Parama.

Harsono. (1986). Ilmu Coaching. Jakarta: Pusat Ilmu Olahraga KONI Pusat. 
Sport Science: Jurnal Sain Olahraga dan Pendidikan Jasmani ISSN 114-562X (Cetak), ISSN XXXX-XXXX(Online)

http://sportscience.ppj.unp.ac.id/index.php/jss/index

Hadi dan Wiwik, Atiq. 2016.”Pengaruh Metode Bermain Terhadap Kemampuan PassingSepakbola Menggunakan Kaki Bagian Dalam” jurnal penelitian dan evaluasi .Hlm. $1-10$.

Jonni. (2010). Dasar-Dasar Pendidikan Jasmani. Padang: UNP Press.

Koger, Robert. (2007).Latihan Dasar Sepak bola Andal Remaja. Klaten: PT Saka Mitra Kompetensi.

Luxbacher, Joseph A. (2011). Sepak bola: Langkah-Langkah Menuju Sukses. Jakarta: PT Raja Grapindo Persada.

Mielke. Danny. (2003). Dasar-Dasar Sepak bola.Bandung: Pakar Raya.

PSSI. (2010). Peraturan Permainan Sepak bola. Jakarta: PSSI.

Schmid, Barry. (2004). Belajar Sepak bola. Jakarta: Gramedia.

Scheunemann S.Timo (2012). Kurikulum Sepak Bola Indonesia. Jakarta: PSSI.

Suharno. (1993). Metodologi Pelatihan. Jakarta: KONI PUSAT Jakarta.

Suwirman. (2015). Penelitian Dasar. Padang: UNP Press

Syafruddin. (1999). Ilmu Kepelatihan Olahraga. Padang: UNP Press.

Syafruddin. (2017). Ilmu Kepelatihan Olahraga. Padang: UNP Press.

Tommura. (2018). Passingand DribblingTogether.www.worldclasscoaching.com,Diakses April 2018

Tim Mata Kulia Sepak Bola. (2010). Buku Ajar Sepak Bola. Padang:Sukabina.

Tim Mata Kulia Sepak Bola. (2012). Buku Ajar Sepak Bola. Padang:Sukabina.

Tim Mata Kuliah Statistik. (2017). Buku Ajar Statistik. Padang Sukabina

Undang-Undang Sistem Keolahragaan Nasional No 3 (2005). Pembinaan dan Pengembangan Olahraga Prestasi Pasal 27 Ayat: 4. Jakarta: PT Sinar Grafika.

Yulifri. (2012). Buku Ajar Permainan Sepakbola. Padang: UNP Press 